\title{
PENYULUHAN DAN PELATIHAN PEMANFAATAN LIMBAH SAMPAH RUMAH TANGGA BERNILAI EKONOMIS DALAM MENCIPTAKAN LINGKUNGAN YANG HIEGIENIS
}

\author{
Inayati Nasrudin ${ }^{1}$, Djoko Pitoyo ${ }^{2}$, Ahmad Munandar $^{3}$, Nurwathi $^{4}$, Ade Geovania Azwar ${ }^{5}$, \\ Sofiani Nalwin Nurbani ${ }^{6}$, Rodiah ${ }^{7}$ \\ 1, 2,3, 4, 5, 6,7 Progran Studi Teknik Industri, Fakultas Teknik, Universitas Sangga Buana
}

${ }^{1}$ korespondensi : inayati.nasrudin@yahoo.com

\begin{abstract}
ABSTRAK
Kecenderungan kerusakan lingkungan hidup semakin kompleks baik di pedesaan maupun perkotaan. Salah satu faktor yang menyebabkan rusaknya lingkungan hidup yang sampai saat ini masih tetap menjadi masalah crusial bagi bangsa Indonesia adalah mengenai pembuangan sampah. Tentu saja masalah ini akan berdampak terhadap pencemaran lingkungan dan polusi yang akan semakin meningkat. Kualitas lingkungan hidup sudah tentu akan terancam. Serta adanya kecenderungan masyarakat pedesaan terbiasa membuang sampah ke sungai atau membakarnya yang dapat menyebabkan pencemaran lingkungan maupun perairan.

Desa Rawabogo merupakan salah satu desa yang terletak di kecamatan Ciwidey, kabupaten Bandung, provinsi Jawa Barat Mayoritas penduduk desa Rawabogo merupakan petani. buruh tani, peternak. Mereka masih belum memahami lingkungan yang sehat dan bersih serta pemanfaatan limbah sampah organik dan anorganik yang memiliki nilai manfaat/jual.

Upaya memecahkan masalah-masalah tersebut melalui pelatihan, penyuluhan mengenai pentingnya menjaga kesehatan lingkungan maupun pengelolaan limbah sampah organik dan anorgnik yang mempunyai nilai tambah/jual. Melalui pelatihan dan penyuluhan tersebut diharapkan para warga Desa Rawabogo dapat meningkatkan kualitas hidup dalam menjaga kesehatan lingkungan serta pemanfaatan limbah sampah yang bernilai tambah/jual.Untuk mencapai hasil yang diharapkan maka Metode yang dipergunakan dalam pelatihan dan penyuluhan diantaranya menggunakan metode (1) Ceramah/pengarahan, (2) Presentasi, (3) Diskusi/tanya jawab, (4) Pelatihan/Penyuluhan dan (5) Evaluasi.
\end{abstract}

Kata Kunci: Pengelolaan Limbah Sampah, Organik, Anorganik, dan Lingkungan Hiegienis

\section{PENDAHULUAN}

\section{Analisis Situasi}

Masalah sampah di Indonesia lagi-lagi menjadi sorotan publik. Melihat perkembangan masalah sampah, agaknya pemerintah memang sudah seharusnya mempercepat perbaikan sistem pengelolaannya. Di Indonesia, sekitar 56\% sampah dikelola oleh pemerintah, sisanya dikelola secara bakar sekitar 35\%, dikubur $7.5 \%$, di kompos 1,6\% dan dengan cara lain 15,9\% 2). Begitupun di Kabupaten Bandung, menurut pendapat Kepala Dinas Lingkungan Hidup (DLH) Kabupaten Bandung, Asep Kusuma, berdasarkan Standar Nasional
Indonesia (SNI), rasio sampah dengan jumlah penduduk kabupaten Bandung yang berjumlah 3 juta 600 ribu jiwa, sampah yang dihasilkan per harinya mencapai 1.440 ton. Artinya satu orang warga menghasilkan sampah 2,5 liter atau $0,4 \mathrm{~kg}$ per harinya. Tentu saja masalah ini akan berdampak terhadap pencemaran lingkungan dan polusi yang akan semakin meningkat. Kualitas lingkungan hidup sudah tentu akan terancam.

Desa Rawabogo merupakan salah satu desa yang terletak di kecamatan Ciwidey, kabupaten Bandung, provinsi Jawa Barat. Desa Rawabogo juga terkenal sebagai salah satu desa wisata dari 
10 desa wisata di kabupaten Bandung. Berdasarkan dari hasil survei sebagian besar penduduknya belum memahami pengelolaan sampah yang ramah lingkungan, masih banyak masyarakat yang membuang sampah ke sungai, atau dibakar. Mereka masih belum memahami lingkungan yang sehat dan bersih (hiegienis) serta pemanfaatan limbah sampah organik dan anorganik yang memiliki nilai tambah/jual.

Berdasarkan uraian di atas maka tim kami dari
Teknik Industri mengadakan kegiatan Pengabdian Pada Masyarakat dilingkungan Desa 2 Kelurahan Rawabogo Kecamatan Ciwidey Kabupaten Bandung. Pengabdian Pada Masyarakat yang melibatkan para warga, dalam mewujudkan masyarakat yang mandiri untuk hidup sehat, bersih serta hiegienis dan menambah wawasan mengenai pemanfaatan limbah sampah organik dan anorganik yang memiliki nilai tambah/jual.

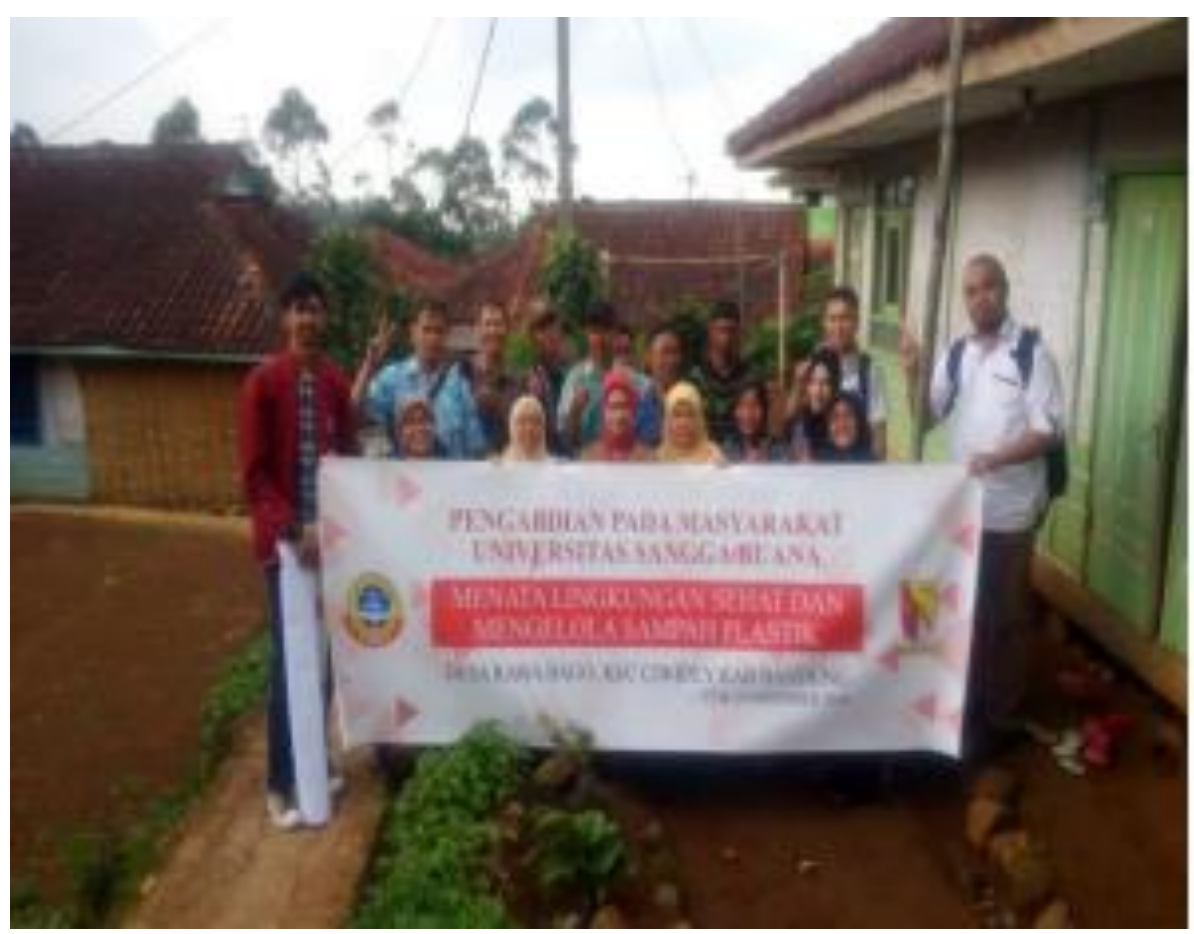

Gambar 1: Tim PKM Teknik Industri Universitas Sangga Buana di Desa Rawabogo

\section{Permasalahan}

Desa Rawabogo merupakan salah satu desa yang terletak di kecamatan Ciwidey. Dengan luas wilayah desa Rawabogo sebagian besar wilayah desa Rawabogo merupakan daerah persawahan dan perkebunan. Mayoritas penduduk desa Rawabogo bermata pencaharian sebagai petani. buruh tani,dan peternak [1].

Berdasarkan dari hasil survei sebagian besar penduduknya belum memahami pengelolaan limbah sampah organik dan anorganik yang ramah lingkungan, masih banyak warga yang membakar baik sampah rumah tangganya maupun hasil pertaniannya. Mereka juga masih belum memahami lingkungan yang sehat dan bersih (hiegienis). Selama ini budaya warga masih membuang sampah organik dan anorganik dalam satu wadah tanpa ada pemilahan. Kurangnya pengetahuan tentang pemanfaatan limbah sampah anorganik dan organik membuat warga tidak peduli terhadap 
dampak yang ditimbulkannya. Apabila diolah dengan baik dan benar, maka limbah sampah tersebut dapat memiliki nilai jual dan menjadi penghasilan tambahan bagi warga.

\section{Solusi Permasalahan}

Berdasarkan atas kondisi permasaalahan tersebut, maka perlu diberikan pengetahuan ataupun wawasan mengenai pentingnya $8 \mathrm{R}$ dalam pemanfaatan limbah sampah organik dan anorganik yang memiliki nilai tambah/jual serta menjaga lingkungan yang sehat, bersih dan hiegienis dalam mewujudkan pelaksanaan visi masyarakat yang mandiri untuk hidup sehat dan misi membangun kemandirian masyarakat untuk hidup sehat di desa Rawabogo.

Sampah adalah sisa hasil buangan dari suatu produk atau barang yang sudah tidak dipergunakan lagi. Namun, walau demikian sampah tersebut masih bisa diolah menjadi barang yang mempunyai nilai atau manfaat. Sampah organik adalah sampah yang berasal dari sisa mahkluk hidup yang mudah terurai secara alami tanpa proses campur tangan manusia. Apabila dikelola dengan tepat, sampah organik dapat dikatakan sebagai sampah ramah lingkungan bahkan sampah yang dapat diolah kembali menjadi sesuatu yang bermanfaat. Sementara sampah anorganik adalah sampah yang sudah tidak dapat dipakai lagi dan sulit terurai. Sampah anorganik yang tertimbun di tanah dapat menyebabkan pencemaran tanah sehingga dapat merusak lapisan tanah.

Dalam UU No 18 tahun 2008 tentang pengelolaan sampah, disebutkan bahwa sampah merupakaan sisa kegiatan sehari-hari manusia atau proses alam yang berbentuk padat atau semi padat berupa organik dan anorganik bersifat dapat terurai atau tidak dapat terurai yang dianggap sudah tidak dapat dipergunakan lagi dan dibuang ke lingkungan [2].

Kepedulian warga Rawago merupakan unsur terpenting sehingga dapat meminimalkan timbunan sampah rumah tangga. Melaksanakan kegiatan pembatasan timbunan sampah dapat dilakukan dengan pendauran ulang dan pemanfaatan kembali sampah, atau yang lebih dikenal dengan sebutan $8 \mathrm{R}$ Reduce (pengurangan), Reuse (penggunaan kembali), Recycle (pendauran ulang) Replace (penggantian), Replant (penanaman kembali), Repair (perbaiki barang-barang yang rusak), Refuse (menolak membeli/mengkonsumsi) dan Rethink (memikirkan kembali) tentunya [3]. melalui upaya-upaya cerdas, efisien, sistematis, menyeluruh, terprogram. dan berkesinambungan.

Upaya strategis yang perlu dilakukan dalam mengatasi persoalan pengelolaan limbah sampah tersebut adalah selain dengan mendorong partisipasi masyarakat dalam pengelolaan limbah sampah dengan melakukan reduksi limbah sampah di sumbernya (rumah tangga) tapi juga melalui program bank sampah. Dengan terintegrasinya gerakan $8 \mathrm{R}$ dan keberadaan bank sampah diharapkan dapat bermanfaat langsung bagi masyaraakat baik dari segi ekonomi maupun membangun lingkungan yang sehat, bersih dan hiegienis.

\section{Target Pencapaian Keluaran}


Target luaran yang diharapkan adalah baik dan benar yang memiliki nilai berkemampuan untuk menjaga lingkungan tambah/jual, melalui beberapa kegiatan seperti hiegienis serta hidup sehat dan mengelola diuraikan dalam tabel dibawah ini:

limbah sampah organik dan anorganik dengan

Tabel 1 Jenis Kegiatan dan Target Pencapaian Keluaran

\begin{tabular}{|c|l|l|l|c|}
\hline No & \multicolumn{1}{|c|}{ Kegiatan } & \multicolumn{1}{|c|}{ Indikator Kegiatan } & \multicolumn{1}{c|}{ Hasil Kegiatan } & Terlaksana \\
\hline 1. & Survey & Pemetaan & $\begin{array}{l}\text { Menemukan permasaalahan } \\
\text { yang ada }\end{array}$ & $20 \%$ \\
\hline 2. & Penyuluhan & Kesehatan Lingkungan & $\begin{array}{l}\text { Pemahaman atas materi } \\
\text { yang telah disampaikan }\end{array}$ & $40 \%$ \\
\hline 4. & Pelatihan & $\begin{array}{l}\text { Pemanfaatan limbah organik } \\
\text { dan anorganik melalui } \\
\text { pendekatan 8R }\end{array}$ & $\begin{array}{l}\text { Pemahaman atas materi } \\
\text { yang telah disampaikan }\end{array}$ & $40 \%$ \\
\hline 5. & Evaluasi & $\begin{array}{l}\text { Diskusi dengan warga serta } \\
\text { pimpinan daerah setempat }\end{array}$ & $\begin{array}{l}\text { Penyerahan drum tempat } \\
\text { sampah }\end{array}$ & $100 \%$ \\
\hline
\end{tabular}

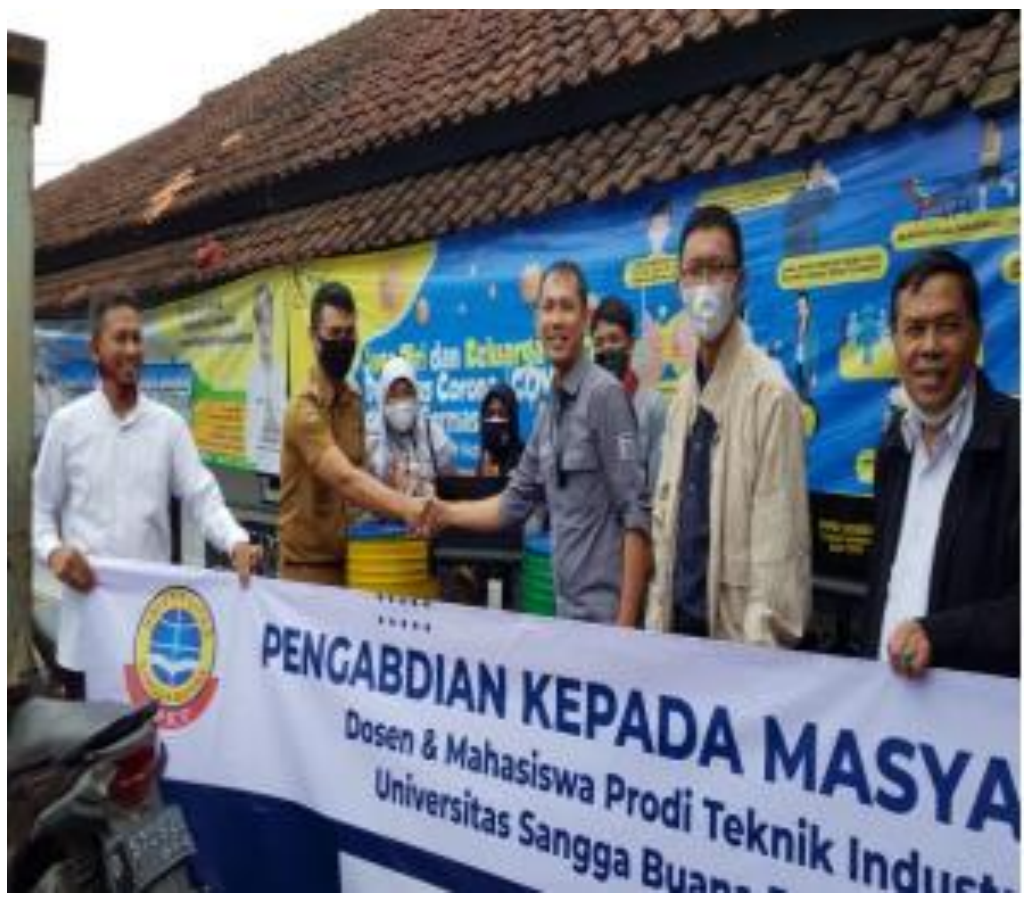

Gambar 2: Proses Evaluasi dan Penyerahan Drum Tempat Sampah

\section{Faktor Pendukung}

1. Respon yang baik dari warga untuk mau mengikuti pelatihan dan penyuluhan
2. Materi yang disampaikan relevan dengan kondisi atau situasi yang dihadapi

3. Mendapatkan dukungan dari pimpinan kelurahan setempat 


\section{Faktor Penghambat}

1. Kesibukan dari masing-masing peserta karena sebagian besar adalah petani

2. Kesulitan dalam mendapatkan tempat yang tepat dalam menjalankan acara

3. Lokasi yang cukup jauh dan membutuhkan waktu untuk berkoordinasi dengan pelaksana kegiatan
4. Kondisi wabah Covid 19 saat ini

\section{METODE}

Pelaksanaan program oleh TIM PPM Teknik Industri dilakukan secara bertahap dimulai dengan pengkondisian warga untuk mengikuti sosialisasi, pelatihan, serta penyuluhan sebagaimana terlihat pada tabel berikut:

Tabel 2 Struktur Program Praktek

\begin{tabular}{|c|l|c|}
\hline NO & \multicolumn{1}{|c|}{ MATERI } & $\begin{array}{c}\text { JAM } \\
\text { PERTEMUAN }\end{array}$ \\
\hline 1 & Mengelola Kesehatan Individual & 1 \\
2 & Mengelola Lingkungan Sehat & 1 \\
3 & Pemanfaatan Sampah Organik dan Anorganik melalui pendekatan 8R & 1 \\
\hline & JUMLAH & 3 \\
\hline
\end{tabular}

\section{Sasaran Kegiatan}

Sasaran kegiatan pengabdian ini adalah warga

Desa Rawabogo, Kecamatan Ciwidey, Kabupaten Bandung. Warga yang diundang untuk hadir adalah ibu-ibu rumah tangga dengan jumlah kurang lebih 12 orang.

\section{Metode Pelaksanaan}

Metode yang digunakan dalam latihan / diklat diantaranya:

1. Ceramah/pengarahan

2. Presentasi

3. Diskusi/tanya jawab

\section{Evaluasi}

\section{HASIL DAN PEMBAHASAN}

\section{Prosedur Kerja}

Apabila pelaksanaan program pelatihan teori dan penyuluhan melibatkan seluruh peserta, maka pada pelaksanaan program praktek tergantung kepada situasi kondisi yaitu prioritas, pemahaman, kesiapan dan kemampuan sumber daya yang dimiliki peserta. Secara alur atau prosedur kerja dapat digambarkan sebagai berikut: 


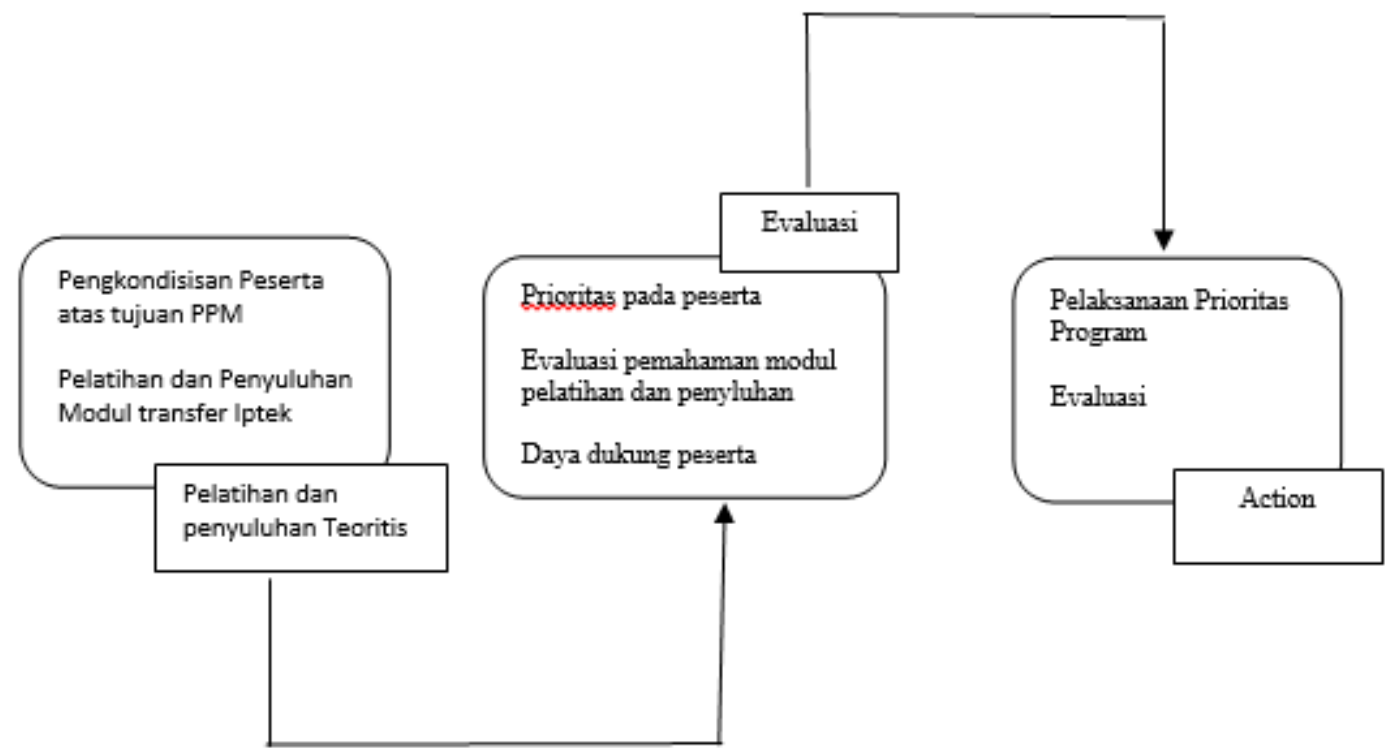

Gambar 1 Alur Kerja Pengabdian

Adapun prosedur yang dilakukan, diawali dengan melakukan pengkondisian seperti sudah diuraikan sebelumnya bahwa permasalahan sebagian besar penduduknya belum memahami pengelolaan sampah yang ramah lingkungan, masih banyak masyarakat yang membuang sampah ke sungai, atau dibakar. Mereka masih belum memahami lingkungan yang sehat dan bersih (hiegienis) serta pemanfaatan limbah sampah organik dan anorganik yang memiliki nilai tambah/jual.

\section{Tahapan Pelaksanaan}

Tahap awal adalah melakukan survai. Berdasarkan hasil survai tersebut ditemukan bahwa sebagian besar warga dalam pengelolaan sampah masih secara konvensional, tanpa memillah-milah terlebih dahulu dan disimpan dalam satu wadah tempat sampah sehingga terbiasa membuang sampah sembarangan dan membakarnya. Menurut penelitian sebelumnya, pengelolaan sampah sebaiknya melalui beberapa tahapan sebagai berikut pertama tahap pemilahan, dilakukan secara manual seperti membedakan limbah sampah organik dan anorganik, tahap berikutnya melakukan pewadahan aktivitas yang dilakukan dengan cara menampung sementara di (wadah/tempat sumber tambah) dan teraakhir dilakukan pengolahan di sumber [4]. Pengolahan tersebut dilakukan mulai dari pengumpulan yang dibedakan melalaui dua proses pemidahan, dan pemilahan selanjutnya pengolahan dilakukan pengangkutan ke pembuangan akhir. Adapun diagram skema teknik operasional pengolahan sampah seharusnya seperti nampak pada gambar di bawah ini: 


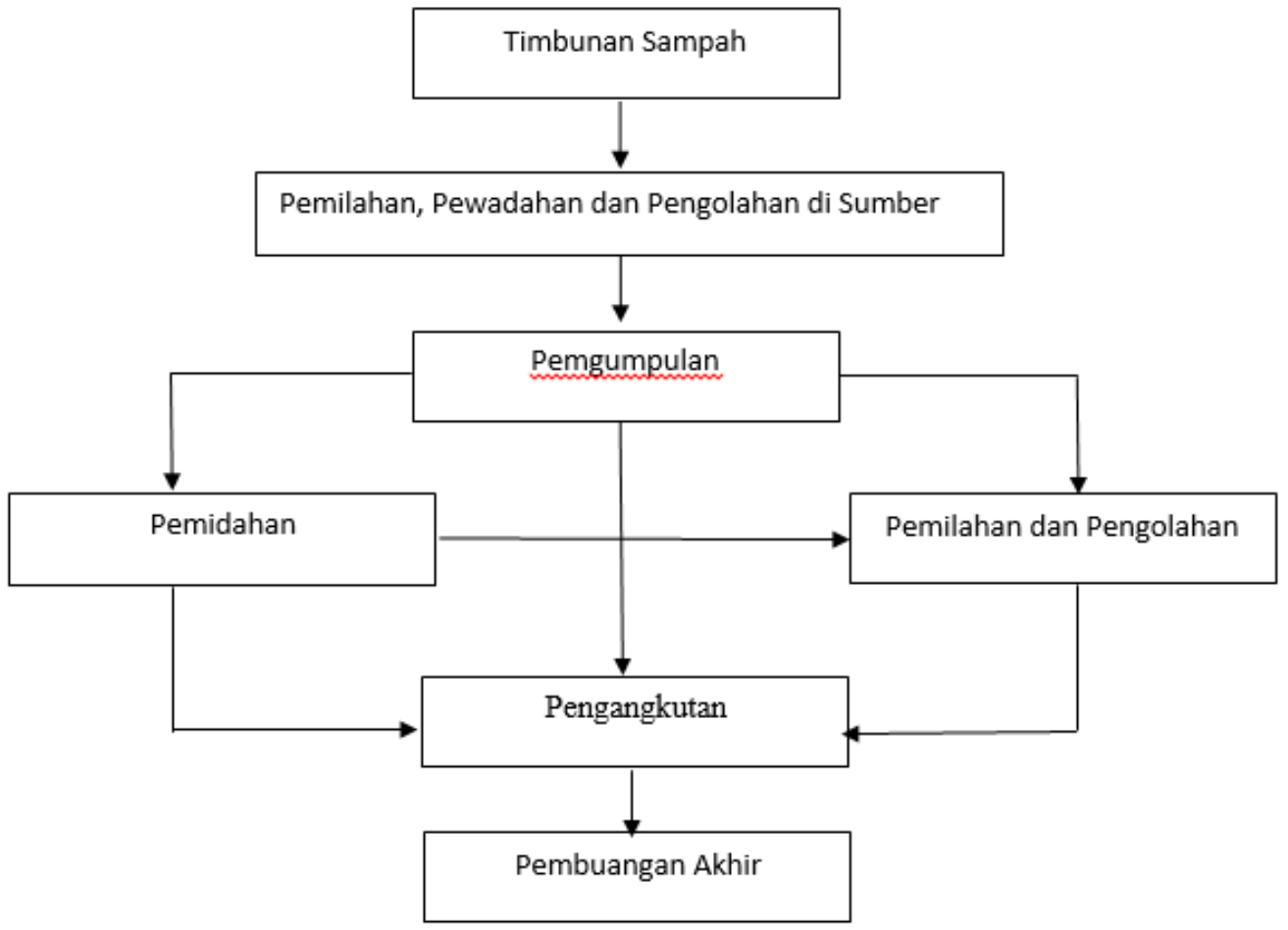

\section{Gambar 2 Teknik Operasional Pengelolaan Persampahan}

Sumber: [4]

Tahap pelaksanaan selanjutnya adalah Tahap terakhir berikutnya adalah kegiatan melakukan pelatihan dan penyuluhan, kegiatan evaluasi dari kegiatan pelatihan dan penyuluhan tersebut merupakan kegiatan pemberian terutama mengukur tingkat keberhasilan dan edukasi atau pengetahuan kepada ibu-ibu tingkat pemahaman warga dalam rumah tangga dengan menyampaikan mengaplikasikan hasil pelatihan dan pentingnya menjaga lingkungan yang sehat, bersih dan hiegienis. Kemudian materi berikutnya, tim menyampaikan konsep 8R dalam pemanfaatan limbah sampah organik dan anorganik yang mempunyai nilai jual/tambah.

Seperti yang dikemukan dari situs https://www.aetra.co.id yang lebih dikenal dengan sebutan 8R Reduce (pengurangan), Reuse (penggunaan kembali), Recycle (pendauran ulang) Replace (penggantian), Replant (penanaman kembali), Repair (perbaiki barang-barang yang rusak), Refuse (menolak membeli/mengkonsumsi) dan Rethink penyuluhan. Disamping itu untuk mengetahui sampai sejauh mana respon warga setelah mendapatkan pelatihan ataupun penyuluhan.

Berdasarkan hasil kunjungan, warga mengalami kesulitan dikarenakan keterabatasan waktu dan kesibukannya sebagai petani sehingga pemanfaatan sampah organik dan anorganik tidak optimal namun warga sudah mulai menjaga lingkungannya tetap sehat dan higienis. Sudah tersedianya Bank Sampah namun masih belum dikoordinirkan dengan optimal karena keterbatasan SDM sehingga (memikirkan kembali). 


\section{KESIMPULAN DAN SARAN}

\section{Kesimpulan}

Kegiatan pengabdian ini berjalan dengan lancar dan sukses. Warga antusias dalam mengikuti pelatihan dan penyuluhan dan langsung mempraktekan di rumah masing-masing. Berdasarkan hasil penyuluhan dan pelatihan, warga sudah mulai memilah-milah sampah dan ditempatkan secara terpisah antara sampah organik dan anorganik serta sudah mulai memahami penerapan konsep 8R Reduce (pengurangan), Reuse (penggunaan kembali), Recycle (pendauran ulang) Replace (penggantian), Replant (penanaman kembali), Repair (perbaiki barang-barang yang rusak), Refuse (menolak membeli/mengkonsumsi) dan Rethink (memikirkan kembali).

Kepedulian warga terhadap kesehatan lingkungan sudah terlihat membaik untuk mencintai dan melestarikan lingkungan. Sudah tersedianya Bank Sampah namun masih belum dikoordinirkan dengan optimal karena keterbatasan SDM .

Dalam pelaksanaan pengelolaan limbah sampah bukan saja peran aktif masyarakat tapi juga perlu adanya dukungan dari pemerintah setempat dalam hal pengawasan serta peran swasta.

\section{Saran}

Diperlukan pendampingan dan pengawasan agar proses perencanaan pengelolaan limbah sampah dapat berjalan dengan lancar sesuai dengan yang diharapkan. Diperlukan peran aktif semua warga dalam pengelolaan mulai dari pemilahan sampai dengan pemanfaatkan kembali menjadi barang yang bermanfaat yang memiliki nilai tambah/nilai jual. Bank Sampah yang sudah terbentuk dapat diaktifkan kembali dan diperlukan penelitian lebih lanjut.

\section{DAFTAR PUSTAKA}

[1] https://id.wikipedia.org/wiki/Rawabogo, _Ciwidey,_Bandung diakses 27 Agustus 2019 diakses pukul 4:29 PM

[2] Irwanto, Pelatihan Masyarakat Dalam Pengelolaan Sampah Rumah Tangga, To Maega Jurnal Pengabdian Masyarakat, Vol: 02, No: 02 Universitas Sultan Ageung Tirtayasa, Agustus 2019 diakses 18 September pukul 2.28 PM

[3] https://www.aetra.co.id/sahabat_aetra/ detail/56/6-R-Reduce-Reuse-Recycle-

Repair-Refuse-Rethink- diakses 20 September 2020 pukul 4.12 PM

[4] Muhammad Zamzami Elamin, Kartika Nuril Ilmi, Tsimaratut Thariah,Yudi Ahmad Zarnuzi, Yanuar Citra Suci, Dwi Ragil Rahmawati, Rizki Kusumawardhani, Dimas Mahendra Dewi P, Rizki Azizir Romhmawati, Pandu Adji BaghashoroIsmi Fuatjia Nasifa, Analisis Pengelolaan Sampah Pada Masyarakat Desa Cisanah Kecamatan sereseh Kabupaten Sampang, Jurnal Kesehatan Lingkungan Vol 10 No 04 Oktober 2018, UNAIR diakses 19 September 2020 pukul 3.20 PM 